\title{
Nitrogen enrichment enhances the dominance of grasses over forbs in a temperate steppe ecosystem
}

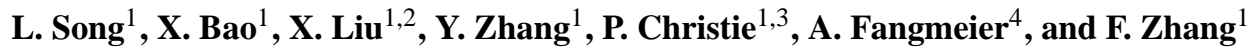 \\ ${ }^{1}$ College of Resources and Environmental Sciences, Key Laboratory of Plant-Soil Interactions of the Ministry of Education, \\ China Agricultural University, Beijing 100193, China \\ ${ }^{2}$ State Key Laboratory of Desert and Oasis Ecology, Xinjiang Institute of Ecology and Geography, Chinese Academy of \\ Sciences (CAS), Urumqi 830011, China \\ ${ }^{3}$ Agri-Environment Branch, Agri-Food and Biosciences Institute, Belfast BT9 5PX, UK \\ ${ }^{4}$ Institute of Plant and Landscape Ecology, University of Hohenheim, 70593 Stuttgart, Germany
}

Received: 30 April 2011 - Published in Biogeosciences Discuss.: 25 May 2011

Revised: 12 August 2011 - Accepted: 15 August 2011 - Published: 26 August 2011

\begin{abstract}
Chinese grasslands are extensive natural ecosystems that comprise $40 \%$ of the total land area of the country and are sensitive to $\mathrm{N}$ deposition. A field experiment with six $\mathrm{N}$ rates $\left(0,30,60,120,240\right.$, and $\left.480 \mathrm{~kg} \mathrm{Nha}^{-1} \mathrm{yr}^{-1}\right)$ was conducted at Duolun, Inner Mongolia, during 2005 and 2010 to identify some effects of $\mathrm{N}$ addition on a temperate steppe ecosystem. The dominant plant species in the plots were divided into two categories, grasses and forbs, on the basis of species life forms. Enhanced $\mathrm{N}$ deposition, even as little as $30 \mathrm{~kg} \mathrm{Nha}^{-1} \mathrm{yr}^{-1}$ above ambient $\mathrm{N}$ deposition $\left(16 \mathrm{~kg} \mathrm{Nha}^{-1} \mathrm{yr}^{-1}\right)$, led to a decline in species richness. The cover of grasses increased with $\mathrm{N}$ addition rate but their species richness showed a weak change across $\mathrm{N}$ treatments. Both species richness and cover of forbs declined strongly with increasing $\mathrm{N}$ deposition as shown by linear regression analysis $(p<0.05)$. Increasing $\mathrm{N}$ deposition elevated aboveground production of grasses but lowered aboveground biomass of forbs. Plant $\mathrm{N}$ concentration, plant $\delta^{15} \mathrm{~N}$ and soil mineral $\mathrm{N}$ increased with $\mathrm{N}$ addition, showing positive relationships between plant $\delta^{15} \mathrm{~N}$ and $\mathrm{N}$ concentration, soil mineral $\mathrm{N}$ and/or applied $\mathrm{N}$ rate. The cessation of $\mathrm{N}$ application in the $480 \mathrm{~kg} \mathrm{Nha}^{-1} \mathrm{yr}^{-1}$ treatment in 2009 and 2010 led to a slight recovery of the forb species richness relative to total cover and aboveground biomass, coinciding with reduced plant $\mathrm{N}$ concentration and soil mineral $\mathrm{N}$. The results show $\mathrm{N}$ deposition-induced changes in soil $\mathrm{N}$ transformations and plant $\mathrm{N}$ assimilation that are closely related to changes in species composition and biomass accumulation in this temperate steppe ecosystem.
\end{abstract}

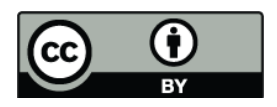

Correspondence to: X. Liu (liu13500@yahoo.com.cn)

\section{Introduction}

Atmospheric nitrogen $(\mathrm{N})$ deposition has become a global concern because of its potential influence on ecosystem productivity, biodiversity and function, especially in many $\mathrm{N}$ deposition "hotspots" worldwide (Phoenix et al., 2006). Anthropogenic reactive $\mathrm{N}$ emissions from intensive livestock production, chemical fertilizer $\mathrm{N}$ application and combustion of fossil fuels and biofuels have accelerated global $\mathrm{N}$ deposition (Galloway et al., 2008). Many terrestrial ecosystems worldwide are therefore facing an $\mathrm{N}$-enriched environment which may lead to changes in plant production and species richness induced by acidification and eutrophication (Vitousek et al., 1997). A decrease in biodiversity or species richness is a serious threat to the maintenance of a stable community (Tilman et al., 2006). Nitrogen deposition can stimulate plant growth and enhance the soil $\mathrm{N}$ pool (Storm and Suss, 2008) and long-term continuous $\mathrm{N}$ inputs may lead to loss of species diversity and changes in species composition (DeFalco et al., 2003). Compared with $\mathrm{NO}_{3}-\mathrm{N}$ addition, Goulding et al. (1998) reported a much larger decrease in species richness of grasses in plots receiving $\mathrm{NH}_{4}-\mathrm{N}$ applications in the Park Grass long-term field experiment, suggesting a larger impact on species richness by acidification than by eutrophication. Stevens et al. (2004) showed that grass species richness in acidic soils decreased linearly with increasing $\mathrm{N}$ deposition (ranging from 5 to $35 \mathrm{~kg} \mathrm{~N} \mathrm{ha}^{-1} \mathrm{yr}^{-1}$ ) in the $\mathrm{UK}$ and each additional increment in long-term $\mathrm{N}$ deposition of approximately $2.5 \mathrm{~kg} \mathrm{~N} \mathrm{ha}^{-1} \mathrm{yr}^{-1}$ is associated with a reduction in species richness of one species. Clark and Tilman (2008) further found that long-term low level N addition $\left(10 \mathrm{~kg} \mathrm{Nha}^{-1} \mathrm{yr}^{-1}\right)$ has reduced plant species numbers by $17 \%$ relative to controls receiving ambient $\mathrm{N}$ deposition

Published by Copernicus Publications on behalf of the European Geosciences Union. 
$\left(6 \mathrm{~kg} \mathrm{Nha}^{-1} \mathrm{yr}^{-1}\right)$, suggesting that chronic but low-level $\mathrm{N}$ deposition may have a greater impact on biodiversity than previously thought. In addition, they also demonstrated that the effects of $\mathrm{N}$ addition on relative plant species number are partially reversible in another experiment in which $\mathrm{N}$ addition was halted for a decade. However, in shortgrass steppe which belongs to a semiarid $\mathrm{N}$-deficient ecosystem, $\mathrm{N}$ addition alone did not show significant changes in species composition while combined water and $\mathrm{N}$ resulted in large shifts (Dodd and Lauenroth, 1979).

Grasslands are the dominant landscape in China and account for $40 \%$ of the national land area (Sun, 2005). They play important roles in supporting the species diversity of plants and animals (Kang et al., 2007). Temperate steppe is a major grassland type in north China and is sensitive to climate change, overgrazing and nutrient supply (Bai et al., 2004; Christensen et al., 2004; Liu et al., 2009). Very limited studies have been conducted on the effects of $\mathrm{N}$ deposition (an important nutrient supply) on Chinese grasslands (Liu et al., 2010). In a 4-yr case study conducted in Inner Mongolia, Bai et al. (2010) demonstrated the tradeoffs and thresholds in effects of $\mathrm{N}$ addition on grassland biodiversity and ecosystem functioning. The 4-yr results from Bai et al. (2010) suggest that the critical threshold for Ninduced species loss to a mature Eurasian grassland may be below $17.5 \mathrm{~kg} \mathrm{Nha}^{-1} \mathrm{yr}^{-1}$, and changes in aboveground biomass, species richness, and plant functional group composition to both mature and degraded ecosystems saturated at approximately $105 \mathrm{~kg} \mathrm{Nha}^{-1} \mathrm{yr}^{-1}$. The effects of $\mathrm{N} \mathrm{de}-$ position on communities are modified by other factors such as plants traits, climatic factors, and abiotic characteristics (Maskell et al., 2010). $\mathrm{N}$ fertilization is a common practice to increase the productivity and forage quality of degraded or intensively-managed grasslands (Conant et al., 2001). It is therefore very important to take into account the tradeoffs between increased aboveground biomass and plant species biodiversity or ecosystem function when evaluating the effects of $\mathrm{N}$ deposition or fertilization. More in-situ $\mathrm{N}$ addition field studies at different sites or regions in China are urgently needed to investigate $\mathrm{N}$ impacts on temperate grasslands. Here we describe a 6-yr field experiment with different $\mathrm{N}$ addition rates at Duolun Experimental Station in Inner Mongolia designed to investigate the response of temperate steppe to elevated $\mathrm{N}$ deposition. The objectives of this study were to test how different functional groups in grasslands respond to elevated $\mathrm{N}$ deposition and to elucidate the role of $\mathrm{N}$ enrichment in determining the loss of plant species.

\section{Materials and methods}

\subsection{Study site}

The research station is located at Duolun county $\left(42^{\circ} 02^{\prime} \mathrm{N}\right.$, $116^{\circ} 17^{\prime} \mathrm{E}, 1324 \mathrm{~m}$ a.s.1.), a semi-arid area in Inner Mongolia

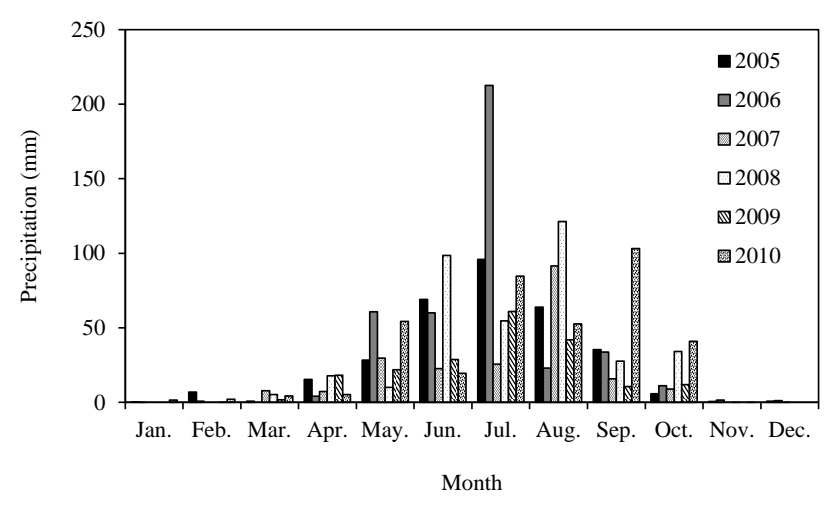

Fig. 1. Monthly precipitation distribution during 2005 and 2010.

Autonomous Region with a mean temperature of $2.1^{\circ} \mathrm{C}$ and maximum and minimum mean monthly temperatures ranging from $18.9{ }^{\circ} \mathrm{C}$ in July to $-17.5^{\circ} \mathrm{C}$ in January. The area is characterized by a continental monsoon climate. Mean annual precipitation is $313 \mathrm{~mm}$, with $94 \%$ distributed from May to October (Fig. 1), and mean potential evaporation of $1748 \mathrm{~mm}$. The soil is classified as a chestnut soil (Chinese classification) or Calcic Luvisol according to the FAO classification, with sand, silt, and clay contents of 62.8 , 20.3 and $16.9 \%$, respectively. Mean soil bulk density and soil $\mathrm{pH}$ (in water) are $1.31 \mathrm{~g} \mathrm{~cm}^{-3}$ and 7.12 , respectively. Soil $(0-10 \mathrm{~cm}$ depth) organic $\mathrm{C}$, total $\mathrm{N}$ and total $\mathrm{P}$ are 12.3, 1.7 and $0.28 \mathrm{~g} \mathrm{~kg}^{-1}$, while Olsen-P and $\mathrm{NH}_{4} \mathrm{OAc}-\mathrm{K}$ are 4.3 and $180 \mathrm{mg} \mathrm{kg}^{-1}$, respectively. According to Zhang et al. (2008), ambient annual $\mathrm{N}$ deposition in this area is about $16 \mathrm{~kg} \mathrm{Nha}^{-1}$. The study site has been fenced off since 2001 to prevent grazing disturbance. The experimental field belongs to a typical steppe community and the dominant plant species in this temperate grassland are Artemisia frigida Willd, Stipa krylovii Roshev., Potentilla acaulis L., Cleistogenes squarrosa (Trin.) Keng, Allium bidentatum Fisch. ex Prokh., and Agropyron cristatum (L.) Gaertn. The major species of grasses and forbs found in the quadrats from 2005 to 2010 are listed in Table 1.

\subsection{Experimental design}

A randomized block design was used with five (2005) or six (after 2006) treatments and five replicate plots of each treatment. Thirty $5 \mathrm{~m} \times 5 \mathrm{~m}$ plots were arranged in a $5 \times 6$ matrix. The distance between any two adjacent plots was $1 \mathrm{~m}$. N fertilizer was added at rates of $0,30,60,120,240$, and $480 \mathrm{~kg} \mathrm{Nha}^{-1} \mathrm{yr}^{-1}$ as $\mathrm{NH}_{4} \mathrm{NO}_{3}$ except in the first year (urea was applied in 2005). The $30 \mathrm{~kg} \mathrm{~N} \mathrm{ha}^{-1} \mathrm{yr}^{-1}$ treatment started in 2006 and $\mathrm{N}$ addition in the $480 \mathrm{~kg} \mathrm{~N} \mathrm{ha}^{-1} \mathrm{yr}^{-1}$ treatment was not applied in 2009 and thereafter to study the recovery from high $\mathrm{N}$ addition on grasslands. The fertilizer for each plot was split into 3 equal foliar applications in early June, July and August. The experiment started in 2005 and continued to 2010 but no measurements were made in 2007 . 
Table 1. Major species of grasses and forbs within the quadrats $(1 \times 1 \mathrm{~m})$ from 2005 to 2010 .

\begin{tabular}{|c|c|c|}
\hline Functional group & & Species \\
\hline Grasses & $\begin{array}{l}\text { Achnatherum sibiricum } \\
\text { Agropyron cristatum } \\
\text { Cleistogenes squarrosa } \\
\text { Leymus chinensis } \\
\text { Setaria viridis } \\
\text { Stipa krylovii }\end{array}$ & \\
\hline Nonlegume Forbs & $\begin{array}{l}\text { Allium neriniflorum } \\
\text { Allium ramosum } \\
\text { Allium senescens } \\
\text { Allium tenuissimum } \\
\text { Androsace umbellata } \\
\text { Artemisia capillaris } \\
\text { Artemisia frigida } \\
\text { Carex korshinskyi } \\
\text { Chamaerhodos erecta } \\
\text { Chenopodium aristatum } \\
\text { Chenopodium glaucum } \\
\text { Cymbaria dahurica } \\
\text { Dianthus chinensis } \\
\text { Dontostemon dentatus } \\
\text { Fagopyrum sagittatum } \\
\text { Gentiana dahurica } \\
\text { Gentiana squarrosa }\end{array}$ & $\begin{array}{l}\text { Heteropappus altaicus } \\
\text { Iris tenuifolia } \\
\text { Ixeris chinensis } \\
\text { Lespedeza davurica } \\
\text { Phlomis umbrosa } \\
\text { Potentilla acaulis } \\
\text { Potentilla anserina } \\
\text { Potentilla bifurca } \\
\text { Potentilla multifida } \\
\text { Potentilla tanacetifolia } \\
\text { Salsola collina } \\
\text { Saposhnikovia divaricata } \\
\text { Scorzonera austriaca } \\
\text { Sibbaldia adpressa } \\
\text { Sonchus arvensis } \\
\text { stellera chamaejasme } \\
\text { Thalictrum petaloideum }\end{array}$ \\
\hline
\end{tabular}

\subsection{Vegetation sampling}

All vegetation sampling except for biomass determination was performed non-destructively. Sampling was conducted in late August in 2005, 2006, 2008, 2009 and 2010 when the sward had the highest biomass each year. Visual estimates were made of vegetation cover and species richness to test for changes in the grassland community in response to $\mathrm{N}$ addition. One permanent quadrat $(1 \times 1 \mathrm{~m})$ was established at each subplot in May 2005. During the measurement a frame $(1 \times 1 \mathrm{~m})$ with 100 equally distributed grids spaced $10 \mathrm{~cm}$ apart was placed above the canopy in each quadrat. The percent cover of each species was estimated visually in all grid cells, the sum of which in each quadrat was considered to represent community cover or functional cover. Species richness was defined as the number of different species in one quadrat.

\subsection{Plant sampling and analysis}

Aboveground vegetation was sampled each year between 25 and 30 August by clipping all plant species at the soil surface. A quadrat $(1 \times 1 \mathrm{~m})$ was placed within each plot randomly except for avoiding overlap with the permanent quadrat used for vegetation sampling and at least $50 \mathrm{~cm}$ away from the edge of the plot to avoid edge effects. All living vascular plants were sorted into species, litter, and standing dead samples which were oven dried for $48 \mathrm{~h}$ at $65^{\circ} \mathrm{C}$ and weighed. All living plants belonging to forbs and grasses were taken as the aboveground biomass for forbs and grasses. Plant
$\mathrm{N}$ concentration and $\mathrm{N}$ isotope composition (expressed by $\delta^{15} \mathrm{~N}$ ) were determined by grinding oven-dried samples to $<100 \mu \mathrm{m}$ followed by micro-Kjeldahl digestion and continuous flow stable isotope ratio mass spectrometry (Delta Plus, Finnigan, Pittsburg, PA).

\subsection{Soil sampling and analysis}

Soil samples from $0-20 \mathrm{~cm}$ depth were collected from all plots with a 5-cm i.d. tube auger and separated into 10$\mathrm{cm}$ depth increments after plant harvest in 2008, 2009 and 2010. One portion of the samples was immediately cooled for transport and stored deep frozen. The frozen soil samples were removed from the refrigerator in the laboratory and within $12 \mathrm{~h}$ a $12 \mathrm{~g}$ moist subsample of soil was extracted with $100 \mathrm{ml} 2 \mathrm{moll}^{-1} \mathrm{KCl}$ solution and shaken for $1 \mathrm{~h}$. The extracts were analyzed for $\mathrm{NO}_{3}-\mathrm{N}$ and $\mathrm{NH}_{4}-\mathrm{N}$ by a continuous flow analysis (TRAACS 2000 Analyzer, Bran and Luebbe, Norderstedt, Germany). Another subsample was weighed in a pre-weighed aluminium can for simultaneous determination of soil water content. Ammonium and nitrate values $\left(\mathrm{mg} \mathrm{N} \mathrm{kg}^{-1}\right)$ were converted to $\mathrm{kg} \mathrm{N} \mathrm{ha}^{-1}$ using soil bulk density and soil depth.

\subsection{Statistical analysis}

All the data were tested for normal distribution before statistical analysis. Statistical analysis of the data was accomplished by standard analysis of variance and pairs of mean values were compared by least significant difference (LSD) at the $5 \%$ level using the SAS software package (SAS Institute, 1996).

\section{Results}

\subsection{Species richness}

Species richness is here expressed as the average number of plant species in the 5 replicates of each treatment determined using a $1.0 \mathrm{~m}^{2}$ quadrat (Fig. 2). There was a negative relationship between $\mathrm{N}$ deposition and species richness in general, especially for forbs which decreased significantly with $\mathrm{N}$ addition rate and over the years, but there was no obvious influence on grasses whose species richness ranged from 3 to 4 and did not show any change over time. In 2005, 2006 and 2008, species richness of grasses was significantly increased by $\mathrm{N}$ addition compared to the zero- $\mathrm{N}$ control plots. In 2009 and 2010, after five and six years of $\mathrm{N}$ addition, no differences in grasses species richness were found across all treatments.

The pattern of response to $\mathrm{N}$ addition in forb species richness showed a decline with increasing $\mathrm{N}$ addition in contrast to the grasses. There were no responses to $\mathrm{N}$ addition in 2005 and 2006, except at $480 \mathrm{~kg} \mathrm{Nha}^{-1} \mathrm{yr}^{-1}$ in which species richness was significantly lower than in the other treatments. 


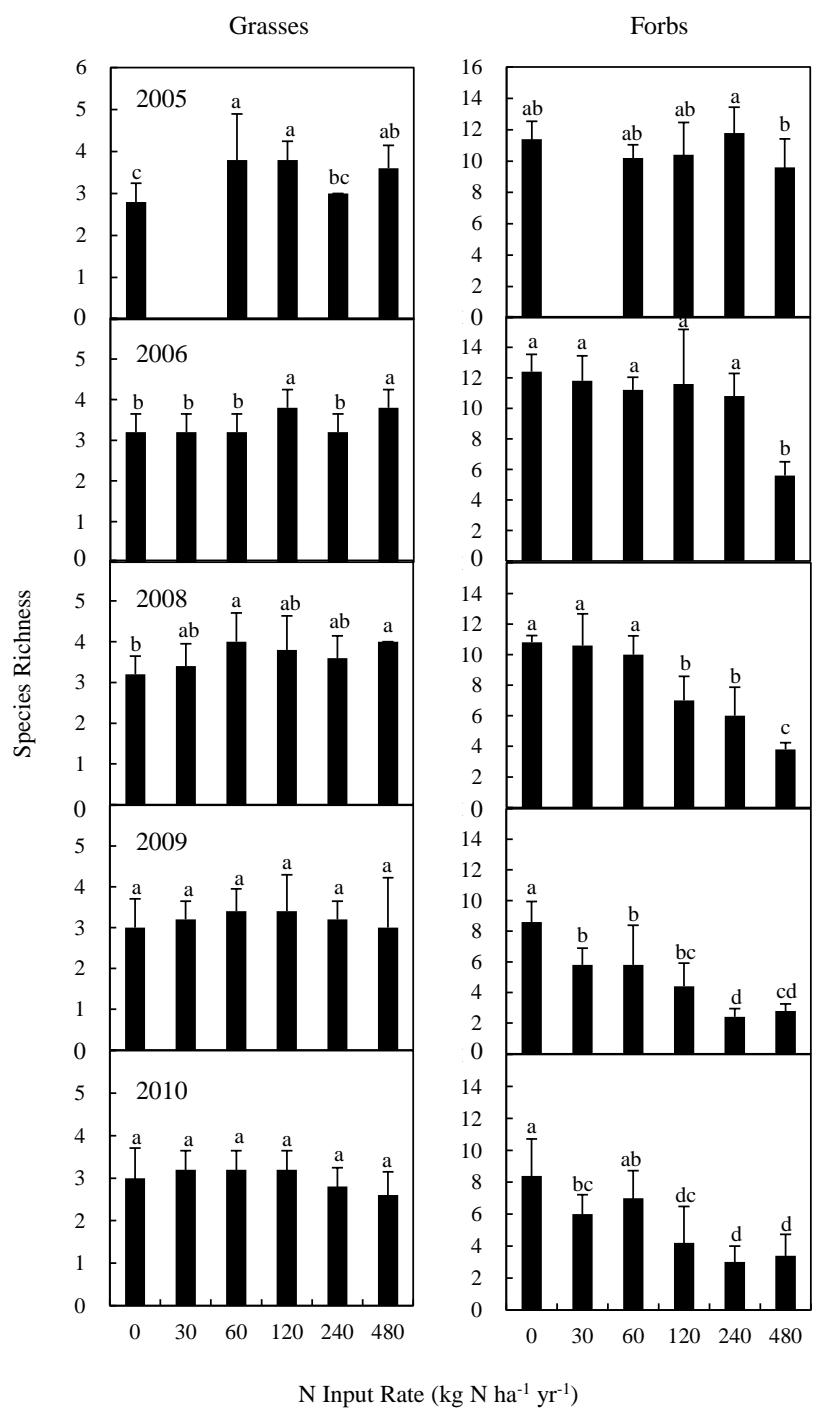

Fig. 2. Relationship between $\mathrm{N}$ addition rate and species richness for grasses (left) and forbs (right) from 2005 to 2010. Different letters at bars indicate treatment differences at $P<0.05$.

In 2008 the species richness decreased significantly at moderate experimental $\mathrm{N}$ rates (i.e. 120 and $240 \mathrm{~kg} \mathrm{~N} \mathrm{ha}^{-1} \mathrm{yr}^{-1}$ ) compared with the control. In 2009 and 2010 there was a further significant decline in species richness of forbs at lower $\mathrm{N}$ rates (i.e. 30 and $60 \mathrm{~kg} \mathrm{Nha}^{-1} \mathrm{yr}^{-1}$ ), indicating a cumulative effect of $\mathrm{N}$ addition on species richness of forbs (Fig. 2). There was no further decline in forb species after cessesion of $\mathrm{N}$ addition in the $480 \mathrm{~kg} \mathrm{~N} \mathrm{ha}^{-1} \mathrm{yr}^{-1}$ treatment after 2009.

\subsection{Aboveground biomass}

Aboveground biomass of grasses tended to increase with $\mathrm{N}$ addition even in the first year at higher $\mathrm{N}$ addition rates (i.e. 240 and $480 \mathrm{~kg} \mathrm{~N} \mathrm{ha}^{-1} \mathrm{yr}^{-1}$ ) (Fig. 3). With cumulative $\mathrm{N} \mathrm{ad-}$ dition, aboveground biomass of grasses increased with time

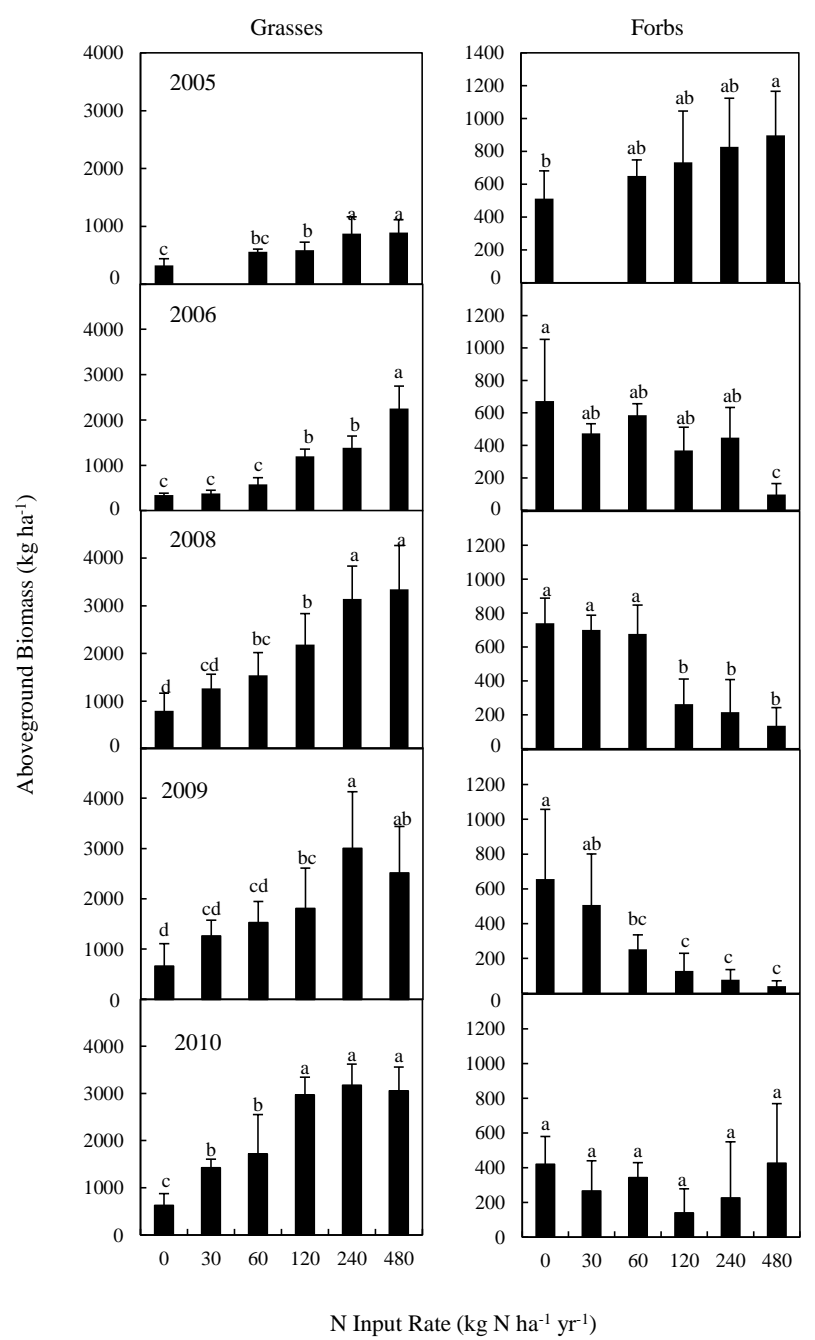

Fig. 3. Response of aboveground biomass of grasses (left) and forbs (right) to $\mathrm{N}$ addition from 2005 to 2010 . Different letters at bars indicate treatment differences at $P<0.05$.

in all treatments, for example from $900 \mathrm{~kg} \mathrm{ha}^{-1}$ to approximately $3000 \mathrm{~kg} \mathrm{ha}^{-1}$ in the $480 \mathrm{~kg} \mathrm{Nha}^{-1} \mathrm{yr}^{-1}$ treatment. After $6 \mathrm{yr}$ of $\mathrm{N}$ addition the grass aboveground biomass saturated at $120 \mathrm{~kg} \mathrm{Nha}^{-1} \mathrm{yr}^{-1}$ treatment and did not show any further increase at higher $\mathrm{N}$ addition rates. In the $480 \mathrm{~kg} \mathrm{~N} \mathrm{ha}^{-1} \mathrm{yr}^{-1}$ treatment the grass aboveground biomass showed no significant change in 2009 and 2010 compared with 2008 because $\mathrm{N}$ addition had ceased.

The trend in forb aboveground biomass was opposite to that of grasses except for the first year (2005) (Fig. 3). In 2005 forb biomass was significantly higher in all $\mathrm{N}$ addition treatments than in the control. By the second year the forb biomass began to exhibit a negative relationship with $\mathrm{N}$ addition rate. There was a significant decline at $480 \mathrm{~kg} \mathrm{~N} \mathrm{ha}^{-1} \mathrm{yr}^{-1}$ from $900 \mathrm{~kg} \mathrm{ha}^{-1}$ in 2005 to $100 \mathrm{~kg} \mathrm{ha}^{-1}$ in 2006, with no apparent change in subsequent years. The aboveground biomass of forbs at $120 \mathrm{~kg} \mathrm{Nha}^{-1} \mathrm{yr}^{-1}$ and 


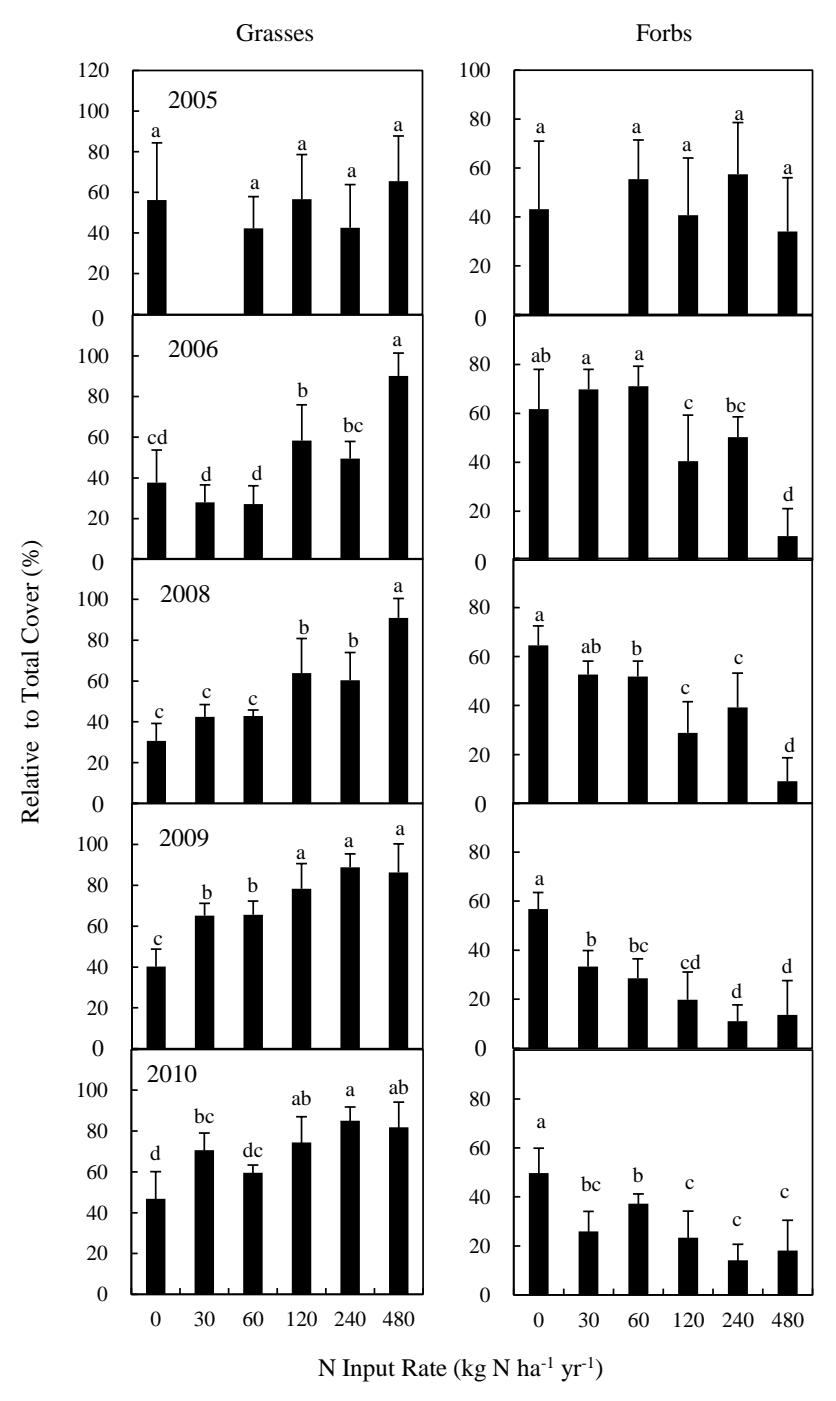

Fig. 4. Relationship between $\mathrm{N}$ addition rate and relative cover of grasses (left) and forbs (right) in relation to total cover during 2005 and 2010. Different letters at bars indicate treatment differences at $P<0.05$.

$240 \mathrm{~kg} \mathrm{~N} \mathrm{ha}^{-1} \mathrm{yr}^{-1}$ declined significantly in 2008 . With continuing $\mathrm{N}$ addition over $6 \mathrm{yr}$ the forb biomass declined significantly down to $30 \mathrm{~kg} \mathrm{Nha}^{-1} \mathrm{yr}^{-1}$ compared with control plots in 2009 . We observed a higher forb aboveground biomass at $480 \mathrm{~kg} \mathrm{~N} \mathrm{ha}^{-1} \mathrm{yr}^{-1}$ in 2010 than in 2009, showing a partial recovery of forb biomass two years after cessation of $\mathrm{N}$ addition.

\subsection{Relative cover}

Figure 4 shows the grass and forb cover as a percentage of the total vegetation cover of the whole plots of each treatment. The cover of grasses and forbs was significantly affected by $\mathrm{N}$ addition, the former increasing and the latter decreasing with increasing $\mathrm{N}$ rate.
In 2005 there were no statistical differences in grass cover across all $\mathrm{N}$ addition rates. Increasing grass cover occurred only at high $\mathrm{N}$ addition rates $\left(\geq 120 \mathrm{~kg} \mathrm{Nha}^{-1} \mathrm{yr}^{-1}\right)$ in 2006 and 2008. In 2009 and 2010, grass cover was significantly higher in almost all $\mathrm{N}$ treatments including the lowest $\mathrm{N}$ rate $\left(30 \mathrm{~kg} \mathrm{Nha}^{-1} \mathrm{yr}^{-1}\right)$ than in the control (Fig. 4). The cessation of $\mathrm{N}$ addition in the $480 \mathrm{~kg} \mathrm{~N} \mathrm{ha}^{-1} \mathrm{yr}^{-1}$ treatment led to a decline in grass cover in 2009 and 2010 (about 80\%) compared with 2008 and 2006 (>90\%).

Forb cover under different $\mathrm{N}$ addition rates followed the opposite trend to grasses. There were no changes in grass cover in 2005 but significant declines were observed in 2006 and 2008 in the plots with $\mathrm{N}$ addition rates equal to or higher than $120 \mathrm{~kg} \mathrm{Nha}^{-1} \mathrm{yr}^{-1}$. Forb cover decreased significantly even at $\mathrm{N}$ addition as low as $30 \mathrm{~kg} \mathrm{~N} \mathrm{ha}^{-1} \mathrm{yr}^{-1}$ in 2009 and 2010. Forb cover was significantly lower in the $480 \mathrm{~kg} \mathrm{~N} \mathrm{ha}^{-1} \mathrm{yr}^{-1}$ treatment than in $240 \mathrm{~kg} \mathrm{~N} \mathrm{ha}^{-1} \mathrm{yr}^{-1}$ over the preceding $3 \mathrm{yr}$ (2006-2008) but the difference between the two treatments disappeared in 2009 and 2010 because $\mathrm{N}$ addition had ceased at the highest $\mathrm{N}$ addition rate from 2009.

\subsection{Plant $\mathrm{N}$ concentration and accumulation}

A positive relationship between $\mathrm{N}$ addition rate and vegetation $\mathrm{N}$ concentration is shown in Fig. 5a and $\mathrm{b}$ and this effect was pronounced in both grasses and forbs. Addition of $480 \mathrm{~kg} \mathrm{~N} \mathrm{ha}^{-1} \mathrm{yr}^{-1}$ showed the highest $\mathrm{N}$ concentrations in both grasses and forbs in 2008. With cessation of $\mathrm{N}$ addition at $480 \mathrm{~kg} \mathrm{Nha}^{-1} \mathrm{yr}^{-1}$, the highest $\mathrm{N}$ concentrations in the two functional groups were found in the $240 \mathrm{~kg} \mathrm{~N} \mathrm{ha}^{-1} \mathrm{yr}^{-1}$ treatment in 2009 and 2010. Significant increases in aboveground $\mathrm{N}$ concentration were found at $\mathrm{N}$ rates at or above 120 and $60 \mathrm{~kg} \mathrm{Nha}^{-1} \mathrm{yr}^{-1}$ for grasses and forbs, respectively, across three years but no significant changes were found at the lower $\mathrm{N}$ rates (except grass $\mathrm{N}$ concentration at $30 \mathrm{~kg} \mathrm{~N} \mathrm{ha}^{-1} \mathrm{yr}^{-1}$ in 2009). The aboveground $\mathrm{N}$ concentration and the change in $\mathrm{N}$ concentration in forbs with $\mathrm{N}$ addition were generally higher than those in grasses across all of the treatments.

Nitrogen accumulation in grasses increased with $\mathrm{N}$ addition, which was enhanced in both increased $\mathrm{N}$ concentration and aboveground biomass under elevated $\mathrm{N}$ input (Fig. 5c). However, due to the reduction in forb biomass and cover, the $\mathrm{N}$ accumulated in forb aboveground parts was significantly lower than that in grasses and followed the opposite trend to $\mathrm{N}$ concentration (Fig. 5d). Similar to the pattern of aboveground $\mathrm{N}$ concentration, $\mathrm{N}$ accumulated in aboveground parts of grasses also showed no differences between the lower $\mathrm{N}$ addition rates especially in 2008 and 2009, unless the rate was equal to or above $120 \mathrm{~kg} \mathrm{~N} \mathrm{ha}^{-1} \mathrm{yr}^{-1}$.

The amounts of $\mathrm{N}$ taken up by grasses were significantly higher at $480 \mathrm{~kg} \mathrm{Nha}^{-1} \mathrm{yr}^{-1}$ than in the other treatments in 2008 and $\mathrm{N}$ uptake in that treatment decreased with the cessation of $\mathrm{N}$ addition in 2009 and 2010. However, the $\mathrm{N}$ taken 

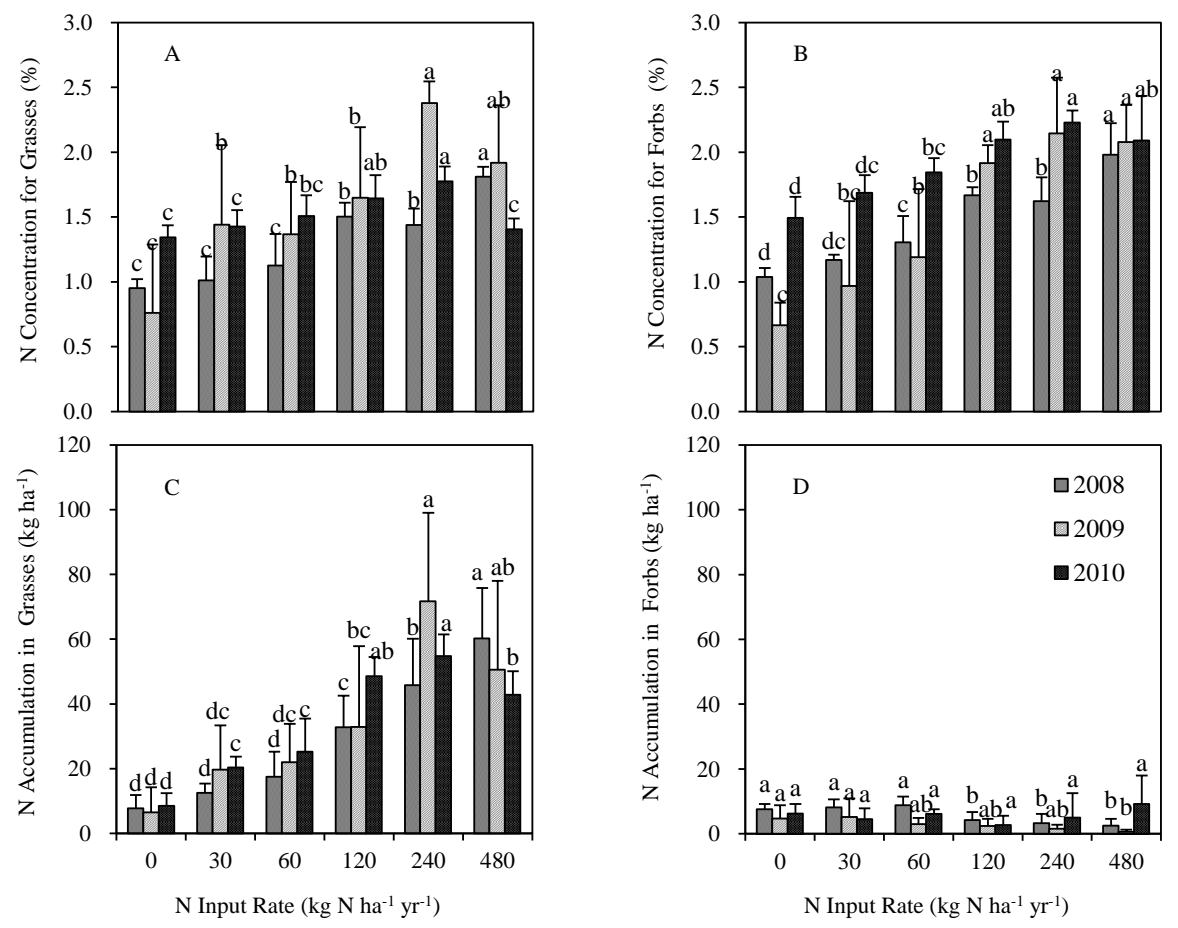

Fig. 5. Responses of aboveground $N$ concentration $(\mathbf{A}, \mathbf{B})$ and $\mathrm{N}$ accumulation $(\mathbf{C}, \mathbf{D})$ in grasses and forbs to $\mathrm{N}$ addition rate from 2008 to 2010. Different letters at bars within the same year indicate treatment differences at $P<0.05$.

up by forbs declined with $\mathrm{N}$ addition, in particular when the addition rate was higher than $120 \mathrm{~kg} \mathrm{Nha}^{-1} \mathrm{yr}^{-1}$, and the higher the $\mathrm{N}$ addition rate became, the lower was the $\mathrm{N}$ accumulation in forbs. This trend ceased at $480 \mathrm{~kg} \mathrm{~N} \mathrm{ha}^{-1} \mathrm{yr}^{-1}$ in the last two years because $\mathrm{N}$ addition had stopped. This changing pattern of $\mathrm{N}$ accumulation indicates that $\mathrm{N}$ deposition or fertilization can stimulate plant growth by increasing $\mathrm{N}$ nutrient supply while also producing changes in species composition.

\subsection{Plant $\delta^{15} \mathrm{~N}$}

Under different addition rates of $\mathrm{N}$ fertilizer $\left(\delta^{15} \mathrm{~N}=6.3 \%\right.$ ) plant aboveground $\delta^{15} \mathrm{~N}$ varied generally from 0 to $6 \%$ o (Fig. 6). Plant $\delta^{15} \mathrm{~N}$ in both grasses and forbs showed positively linear relationships with $\mathrm{N}$ addition rate if the $480 \mathrm{~kg} \mathrm{~N} \mathrm{ha}^{-1} \mathrm{yr}^{-1}$ treatment which ceased in 2009 and 2010 is omitted. Plant $\delta^{15} \mathrm{~N}$ values were close to zero (equal to natural ${ }^{15} \mathrm{~N}$ abundance) in the control, consistent with the background soil $\delta^{15} \mathrm{~N}$ value $(0.2 \%$ ) and all these values in added $\mathrm{N}$ treatments were higher in 2010 than in 2009. The plant $\delta^{15} \mathrm{~N}$ values for both grasses and forbs in the $480 \mathrm{~kg} \mathrm{Nha}^{-1} \mathrm{yr}^{-1}$ treatment were lower than those in the $240 \mathrm{~kg} \mathrm{~N} \mathrm{ha}^{-1} \mathrm{yr}^{-1}$ treatment in both years. Compared with grasses, $\delta^{15} \mathrm{~N}$ in forbs increased faster under elevated $\mathrm{N}$ addition in both 2009 and 2010. We also found that plant $\delta^{15} \mathrm{~N}$ in both forbs and grasses increased significantly and linearly with increasing plant $\mathrm{N}$ concentration (data not shown).

\subsection{Soil mineral N}

Soil mineral $\mathrm{N}\left(\mathrm{NH}_{4}-\mathrm{N}\right.$ and $\left.\mathrm{NO}_{3}-\mathrm{N}\right)$ distributions at the $0-10$ and $10-20 \mathrm{~cm}$ soil depths are shown in Fig. 7. Most of $\mathrm{NH}_{4}{ }^{-}$ $\mathrm{N}$ in this part of the soil profile accumulated in the top $10 \mathrm{~cm}$ while $\mathrm{NO}_{3}-\mathrm{N}$ mainly appeared at $10-20 \mathrm{~cm}$. Soil mineral $\mathrm{N}$ was significantly higher at $\mathrm{N}$ rate $\geq 120 \mathrm{~kg} \mathrm{~N} \mathrm{ha}^{-1} \mathrm{yr}^{-1}$ (2008) or $60 \mathrm{~kg} \mathrm{~N} \mathrm{ha}^{-1} \mathrm{yr}^{-1}$ (2009 and 2010) compared with the control. In $2008 \mathrm{NH}_{4}-\mathrm{N}$ was significantly higher at $480 \mathrm{~kg} \mathrm{Nha}^{-1} \mathrm{yr}^{-1}$ than in the control or $30 \mathrm{~kg} \mathrm{Nha}^{-1} \mathrm{yr}^{-1}$, and there were no differences among the other treatments. $\mathrm{NO}_{3}-\mathrm{N}$ was lower than $\mathrm{NH}_{4}-\mathrm{N}$ across all of the treatments in the $0-10 \mathrm{~cm}$ soil layer and increased slightly with increasing $\mathrm{N}$ addition rate. Nitrate- $\mathrm{N}$ at $480 \mathrm{~kg} \mathrm{Nha}^{-1} \mathrm{yr}^{-1}$ was significantly higher than in the other $\mathrm{N}$ treatments. The ratios of $\mathrm{NH}_{4}-\mathrm{N}$ to $\mathrm{NO}_{3}-\mathrm{N}$ were not affected by $\mathrm{N}$ addition treatment in the $0-10 \mathrm{~cm}$ soil layer but they declined from 2.2 at the control to 1.1 at the highest $\mathrm{N}$ rate in the top 0-20 cm soil (2010). In 2009 and 2010 significant increases in $\mathrm{NH}_{4}-\mathrm{N}$ and $\mathrm{NO}_{3}-\mathrm{N}$ were found from the $\mathrm{N}$ rate of $60 \mathrm{~kg} \mathrm{~N} \mathrm{ha}^{-1} \mathrm{yr}^{-1}$ in both soil layers. Compared with the $240 \mathrm{~kg} \mathrm{Nha}^{-1} \mathrm{yr}^{-1}$ treatment, a significant decline in mineral $\mathrm{N}$ in the $480 \mathrm{~kg} \mathrm{Nha}^{-1} \mathrm{yr}^{-1}$ treatment was found because of the cessation of $\mathrm{N}$ addition in the last two years of the study. 

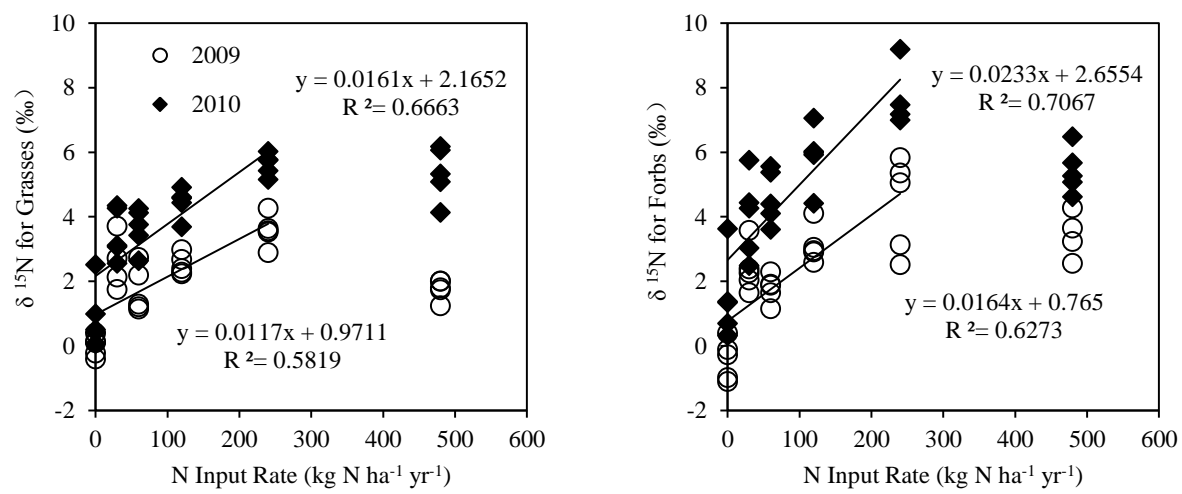

Fig. 6. Relationships between $\mathrm{N}$ addition rate and aboveground $\delta^{15} \mathrm{~N}$ value of grasses (left) and forbs (right) during 2009 and 2010.

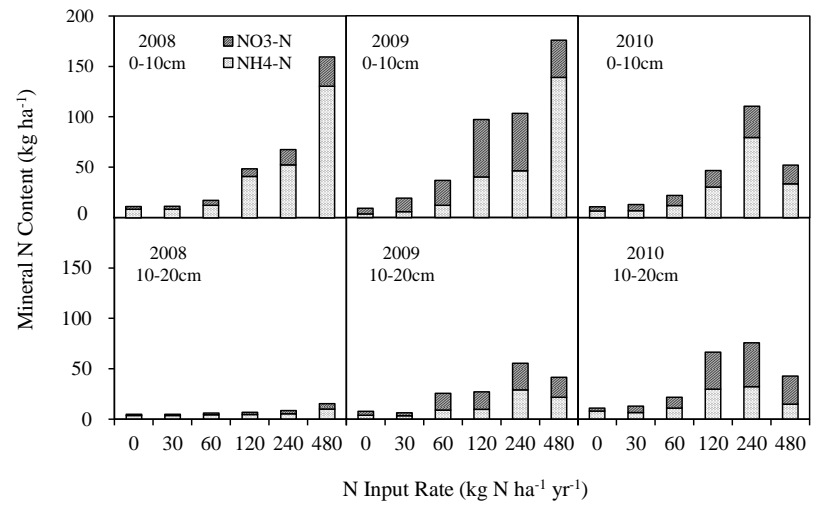

Fig. 7. Soil mineral $\mathrm{N}$ content in the top $20 \mathrm{~cm}$ of the soil profile from 2008 to 2010 .

\section{Discussion}

\section{1 $\mathrm{N}$ addition effects on vegetation, plant $\mathrm{N}$ assimilation and $\delta^{15} \mathrm{~N}$}

In the present study we observed a positive and dose-related relationship between $\mathrm{N}$ addition and cover or biomass of grasses while the forbs showed the opposite trend. Furthermore, the changes in species composition were mainly due to the decline in forb species richness under $\mathrm{N}$-enriched conditions. No significant variations were found in grass species richness at elevated $\mathrm{N}$ inputs. A significant decline in forb species richness occurred even at the lowest $\mathrm{N}$ addition rate of $30 \mathrm{~kg} \mathrm{~N} \mathrm{ha}^{-1} \mathrm{yr}^{-1}$ in both 2009 and 2010 (Fig. 2). Compared to 2005, the forb species richness in 2010 at an $\mathrm{N}$ addition rate of $240 \mathrm{~kg} \mathrm{~N} \mathrm{ha}^{-1} \mathrm{yr}^{-1}$ was reduced from 12.0 to 3.0 , a very large loss of species biodiversity. No further decline in forb species occurred at the highest $\mathrm{N}$ addition rate $\left(480 \mathrm{~kg} \mathrm{~N} \mathrm{ha}^{-1} \mathrm{yr}^{-1}\right)$ in 2009 or 2010 compared with $240 \mathrm{~kg} \mathrm{Nha}^{-1} \mathrm{yr}^{-1}$ due to zero $\mathrm{N}$ application in the $480 \mathrm{~kg} \mathrm{Nha}^{-1} \mathrm{yr}^{-1}$ treatment during the final two years of the study. These are consistent with the findings of Clark and
Tilman (2008) who reported that even $\mathrm{N}$ additions as low as $10 \mathrm{~kg} \mathrm{Nha}^{-1} \mathrm{yr}^{-1}$ led to a significant loss of sensitive grass species in an acidic grassland in Minnesota and the cessation of $\mathrm{N}$ addition for a decade can result in recovery of the main grass species.

Nitrogen deposition has been regarded as the third most important driver of declining species richness after land use change and climate change (Sala et al., 2000). Nitrogen limits plant growth in most terrestrial ecosystems but both $\mathrm{N}$ gradient and $\mathrm{N}$ addition experiments predict that there is a critical load above which species richness will decline as biomass production increases (Grime, 1973; Gross et al., 2000; Vitousek et al., 2002). The critical load was found to be 15$25 \mathrm{~kg} \mathrm{~N} \mathrm{ha}^{-1} \mathrm{yr}^{-1}$ for sub-atlantic semi-dry calcareous grassland, $10-20 \mathrm{~kg} \mathrm{Nha}^{-1} \mathrm{yr}^{-1}$ for heath meadows and humid swards, and $5-10 \mathrm{~kg} \mathrm{Nha}^{-1} \mathrm{yr}^{-1}$ for alpine and subalpine grassland (Bobbink et al., 2010). There have been numerous studies on the mechanisms of change in species composition under elevated N deposition. Suding et al. (2005) proposed that two hypotheses, trait-neutral and trait-based, operate simultaneously in relation to the biodiversity-production relationship. On one hand, rare species are at most risk of loss because of their initial low abundance as productivity is enhanced. On the other hand, competition shifts from belowground nutrient resources to aboveground resources (such as light) and, as a result, species that are habituated to unfertilized conditions or constrained in their use of aboveground resources will be more likely to disappear. An additional factor is invasion by exotic grasses which have higher $\mathrm{N}$ use efficiency than the native species as soil available $\mathrm{N}$ increases with elevated $\mathrm{N}$ deposition (Rao et al., 2009). Furthermore, all of these factors will be affected by underground process changes as $\mathrm{N}$ deposition increases (Dupre et al., 2010). Soil $\mathrm{pH}$ is strongly correlated with $\mathrm{N}$ deposition and shows a negative association with the proportion of grasses in acidic grassland (Stevens et al., 2004). Species number and diversity are also negatively correlated with increasing $\mathrm{N}: \mathrm{P}$ and $\mathrm{N}: \mathrm{K}$ ratios in heathlands and grasslands (Koerselman and 
Meuleman, 1996; Roem and Berendse, 2000). In our study area, $\mathrm{N}$ was the most limiting nutrient for plant growth, while $\mathrm{P}$ limitation occurred only in $\mathrm{N}$ saturated conditions and $\mathrm{K}$ was not limiting in any situation (Gong et al., 2011). Losses in species richness were mainly due to decreases in perennial forbs while no significant changes occurred in annuals, shrubs and semi-shrubs, or annual forbs in our steppe (Song et al., 2011). This is in accordance with Lauenroth et al. (1978) who found that changes in community structure occurred mainly in several dominant groups. Different species responses to $\mathrm{N}$ addition may also be related to species functional traits such as root depth, $\mathrm{N}$ use efficiency, and mycorrhizal colonization which are associated with strategies for species adaptation to variable nutrient conditions (Ren et al., 2011). In addition, soil water content and annual precipitation are also important factors which can interact positively with $\mathrm{N}$ to influence ecosystem functioning (Chen et al., 2011). When $\mathrm{N}$ or water is added independently to shortgrass steppe in North America, aboveground biomass can increase correspondingly by 100 or $250 \%$, but it can increase by $700 \%$ with addition of water and $\mathrm{N}$ together (Lauenroth et al., 2008). In the present study the increase in soil mineral $\mathrm{N}$, especially $\mathrm{NO}_{3}-\mathrm{N}$, under elevated $\mathrm{N}$ deposition may be the main explanation for changes in species richness and aboveground biomass of both grasses and forbs. Nitrogen deposition can also influence soil $\mathrm{C}$ storage and $\mathrm{C}: \mathrm{N}$ ratio through biotic and abiotic pathways, which further influence soil gross $\mathrm{N}$ mineralization and microbial respiration (West et al., 2006).

Nitrogen deposition has favored grasses at the expense of forbs in our study. This is in accordance with the results of Stevens et al. (2006) who have conducted studies along a geographical deposition gradient in Great Britain, and Carroll et al. (2003) who found regular applications of ammonium nitrate $\left(35-140 \mathrm{~kg} \mathrm{~N} \mathrm{ha}^{-1} \mathrm{yr}^{-1}\right.$ ) resulted in significant decreases in the cover of individual forbs. Similar responses involving changes in species composition in favor of grasses have also been observed in other studies (Bobbink, 1991; Mountford et al., 1993; Wedin and Tilman, 1996). One possible explanation for this phenomenon is that grasses have higher $\mathrm{N}$ use efficiency (NUE) than forbs, resulting in faster growth and suppression of the growth of other plant species (Peppler-Lisbach and Petersen, 2001). Our work provides evidence for this mechanism. We found increased aboveground biomass and $\mathrm{N}$ accumulation in grasses but decreased aboveground biomass and $\mathrm{N}$ accumulation in forbs with increasing $\mathrm{N}$ addition (Figs. 3 and 5). In contrast, plant $\mathrm{N}$ concentration and $\delta^{15} \mathrm{~N}$ showed greater responses by forbs than by grasses under $\mathrm{N}$ enrichment conditions (Figs. 5 and 6), suggesting that forbs are more "sensitive" to $\mathrm{N}$ addition.

Previous studies have predicted that foliar $\delta^{15} \mathrm{~N}$ can be considered to be a good indicator of the source of $\mathrm{N}$ for plants (Amundson et al., 2003; Pardo et al., 2006; Kahmen et al., 2008). Assuming that plant $\delta^{15} \mathrm{~N}$ shows a positive relationship with $\mathrm{N}$ source, this pattern indicates that increasing amounts of mineral $\mathrm{N}$ lead to more ${ }^{15} \mathrm{~N}$ enrichment in soils with altered $\mathrm{N}$ transformation rates and ${ }^{14} \mathrm{~N}$ enriched $\mathrm{N}$ losses through $\mathrm{NO}_{3}-\mathrm{N}, \mathrm{N}_{2} \mathrm{O}$ and $\mathrm{N}_{2}$ (Kahmen et al., 2008). Denitrification can be regarded as an important pathway of $\mathrm{N}$ loss in temperate grassland (Tilsner et al., 2003a, b), leading to greater enrichment of $\mathrm{NO}_{3}-\mathrm{N}$ than $\mathrm{NH}_{4}-\mathrm{N}$ in ${ }^{15} \mathrm{~N}$. When the $\mathrm{N}$ addition rate was higher than $60 \mathrm{~kg} \mathrm{Nha}^{-1} \mathrm{yr}^{-1}$, there was a significant accumulation of $\mathrm{NO}_{3}-\mathrm{N}$ which was much more readily assimilated by plants due to its higher mobility under semi-arid conditions compared to $\mathrm{NH}_{4}-\mathrm{N}$ (Houlton et al., 2007). With increasing $\mathrm{N}$ addition rate the $\mathrm{NH}_{4}-\mathrm{N} / \mathrm{NO}_{3}-\mathrm{N}$ ratio (according to Fig. 7) declined in the soil, leading to plants taking up more and more $\mathrm{NO}_{3}-\mathrm{N}$ over $\mathrm{NH}_{4}-\mathrm{N}$. Consequently plant $\delta^{15} \mathrm{~N}$ will also increase with declining $\mathrm{NH}_{4}-\mathrm{N} / \mathrm{NO}_{3}-\mathrm{Nin}$ the soil. Futhermore, because the $\delta^{15} \mathrm{~N}$ of our fertilizer $(6.3 \%$ ) was above natural abundance, more $\mathrm{N}$ assimilated by plants would also result in higher $\delta^{15} \mathrm{~N}$ in the aboveground plant parts. The higher $\delta^{15} \mathrm{~N}$ values in forbs at the same $\mathrm{N}$ addition rate than grasses suggests that $\mathrm{N}$ uptake by forbs could be mostly from transformed added $\mathrm{N}$ (with higher ${ }^{15} \mathrm{~N}$ enrichment) whereas grass $\mathrm{N}$ assimilation was mainly from the original $\mathrm{N}$ source. The cessation of fertilizer $\mathrm{N}$ application in 2009 and 2010 produced a decline in $\delta^{15} \mathrm{~N}$ in both grasses and forbs in the plots receiving $480 \mathrm{~kg} \mathrm{Nha}^{-1} \mathrm{yr}^{-1}$ compared to $240 \mathrm{~kg} \mathrm{Nha}^{-1} \mathrm{yr}^{-1}$, clearly showing the effect of $\mathrm{N}$ source.

\section{2 $\mathrm{N}$ addition effects on the soil mineral $\mathrm{N}$ pool}

As $\mathrm{N}$ addition rate increased, more available mineral $\mathrm{N}$ accumulated in the soil profile. The amount of residual mineral $\mathrm{N}$ (in particular $\mathrm{NO}_{3}-\mathrm{N}$ ) can affect soil $\mathrm{N}$ transformations (i.e. mineralization and nitrification) and also indicates whether or not the soil is $\mathrm{N}$ saturated. In the present study $\mathrm{NH}_{4}$ $\mathrm{N}$ accumulated mainly in the topsoil $(0-10 \mathrm{~cm})$ and $\mathrm{NO}_{3}-$ $\mathrm{N}$ accumulated substantially when the $\mathrm{N}$ addition rate was higher than $120 \mathrm{~kg} \mathrm{~N} \mathrm{ha}^{-1} \mathrm{yr}^{-1}$ either at $0-10$ or $10-20 \mathrm{~cm}$ soil depth and the ratio of $\mathrm{NH}_{4}-\mathrm{N}$ to $\mathrm{NO}_{3}-\mathrm{N}$ declined sharply in the highest $\mathrm{N}$ addition treatment (according to Fig. 7). The accumulation of $\mathrm{NO}_{3}-\mathrm{N}$ in the soil profile (Fig. 7) can be considered to indicate incipient soil $\mathrm{N}$ saturation (Aber et al., 1998; Goulding et al., 1998). This may explain the decline in forb composition under elevated $\mathrm{N}$ deposition in our study because under $\mathrm{N}$-saturated conditions other factors (e.g. P, K, light and/or water) rather than $\mathrm{N}$ become major factors limiting plant growth. Grassland species (i.e. forbs) which are sensitive to $\mathrm{N}$ inputs will be at risk of poor survival under elevated $\mathrm{N}$ deposition-induced soil $\mathrm{N}$ saturation.

\section{Conclusions}

Our results indicate that increased $\mathrm{N}$ deposition can lead to loss of forb species richness in temperate steppe ecosystems. Even $\mathrm{N}$ inputs as low as $30 \mathrm{~kg} \mathrm{Nha}^{-1} \mathrm{yr}^{-1}$ will lead 
to changes in species composition, showing an increase in aboveground biomass and cover of grasses and a decrease in forbs together with a decrease in species richness of forbs. A two-year cessation of $\mathrm{N}$ addition of $480 \mathrm{~kg} \mathrm{Nha}^{-1} \mathrm{yr}^{-1}$ showed a recovery effect on forb biomass, cover and species richness. With increased $\mathrm{N}$ addition, plants increased their $\mathrm{N}$ assimilation and the $\delta^{15} \mathrm{~N}$ value increased in both grasses and forbs, indicating that changes in soil $\mathrm{N}$ sources comprised fertilizer and both soil $\mathrm{N}$ forms. When the $\mathrm{N}$ addition rate was above $60 \mathrm{~kg} \mathrm{~N}^{-1} \mathrm{yr}^{-1}, \mathrm{NO}_{3}-\mathrm{N}$ contents increased sharply in the top $20 \mathrm{~cm}$ of the soil profile until at the highest $\mathrm{N}$ addition rate the ratio of $\mathrm{NH}_{4}-\mathrm{N}$ to $\mathrm{NO}_{3}-\mathrm{N}$ declined to 1.1 compared with 2.2 in the zero- $\mathrm{N}$ control. Increasing soil $\mathrm{NO}_{3}-\mathrm{N}$ and declining $\mathrm{NH}_{4}-\mathrm{N} / \mathrm{NO}_{3}-\mathrm{N}$ ratio with $\mathrm{N}$ addition can lead to changes in soil $\mathrm{N}$ transformation rates, soil enrichment with ${ }^{15} \mathrm{~N}$ and eventually soil $\mathrm{N}$ saturation, all of which are closely related to changes in plant community species richness.

Acknowledgements. This work was supported by the Hundred Talent Program of the Chinese Academy of Sciences, the National Natural Science Foundation of China (NSFC) (41071151), the Innovative Group Grants from NSFC (30821003), and the SinoGerman DFG Research Training Group (GK1070). The authors acknowledge Bai Wenming for his kind help during this 6-yr study.

Edited by: A. R. Mosier

\section{References}

Aber, J., McDowell, W., Nadelhoffer, K., Magill, A., Berntson, G., Kamakea, M., McNulty, S., Currie, W., Rustad, L., and Fernandez, I.: Nitrogen saturation in temperate forest ecosystems - Hypotheses revisited, Bioscience, 48, 921-934, 1998.

Amundson, R., Austin, A. T., Schuur, E. A. G., Yoo, K., Matzek, V., Kendall, C., Uebersax, A., Brenner, D., and Baisden, W. T.: Global patterns of the isotopic composition of soil and plant nitrogen, Global Biogeochem. Cy., 17, 1031, doi:10.1029/2002GB001903, 2003.

Bai, Y. F., Han, X. G., Wu, J. G., Chen, Z. Z., and Li, L. H.: Ecosystem stability and compensatory effects in the Inner Mongolia grassland, Nature, 431, 181-184, 2004.

Bai, Y. F., Wu, J. G., Clark, C. M., Naeem, S., Pan, Q. M., Huang, J. H., Zhang, L. X., and Han, X. G.: Tradeoffs and thresholds in the effects of nitrogen addition on biodiversity and ecosystem functioning: evidence from inner Mongolia Grasslands, Global Change Biol., 16, 358-372, 2010.

Bobbink, R.: Effects of nitrogen enrichment in Dutch chalk grassland, J. Appl. Ecol., 28, 28-41, 1991.

Bobbink, R., Braun, S., Nordin, A., Power, S., Schütz, K., Strengbom, J., Weijters, M., and Tomassen, H.: Review and Revision of Empirical Critical Loads and Dose-response Relationships, Proceedings of an Expert Workshop, Noordwijkerhout, 23-25 June 2010.

Carroll, J. A., Caporn, S. J. M., Johnson, D., Morecroft, M. D., and Lee, J. A.: The interactions between plant growth, vegetation structure and soil processes in semi-natural acidic and calcare- ous grasslands receiving long-term inputs of simulated pollutant nitrogen deposition, Environ. Pollut., 121, 363-376, 2003.

Chen, Q., Hooper, D. U., and Lin, S.: Shifts in species composition constrain restoration of overgrazed grassland using nitrogen fertilization in Inner Mongolian steppe, China, PLoS One, 6, e16909, doi:10.1371/journal.pone.0016909, 2011.

Christensen, L., Coughenour, M. B., Ellis, J. E., and Chen, Z. Z.: Vulnerability of the Asian typical steppe to grazing and climate change, Climatic Change, 63, 351-368, 2004.

Clark, C. M. and Tilman, D.: Loss of plant species after chronic low-level nitrogen deposition to prairie grasslands, Nature, 451, 712-715, 2008.

Conant, R. T., Paustian, K., and Elliott, E. T.: Grassland management and conversion into grassland: Effects on soil carbon, Ecol. Appl., 11, 343-355, 2001.

DeFalco, L. A., Bryla, D. R., Smith-Longozo, V., and Nowak, R. S.: Are Mojave Desert annual species equal?, Resource acquisition and allocation for the invasive grass Bromus madritensis subsp rubens (Poaceae) and two native species, Am. J. Bot., 90, 10451053, 2003.

Dodd, J. L. and Lauenroth, W. K.: Analysis of the response of a grassland ecosystem to stress, in: Perspectives in grassland ecology, edited by: French, N. R., Springer-Verlag, New York, 43$58,1979$.

Dupre, C., Stevens, C. J., Ranke, T., Bleeker, A., Peppler-Lisbach, C., Gowing, D. J. G., Dise, N. B., Dorland, E., Bobbink, R., and Diekmann, M.: Changes in species richness and composition in European acidic grasslands over the past 70 years: the contribution of cumulative atmospheric nitrogen deposition, Global Change Biol., 16, 344-357, 2010.

Galloway, J. N., Townsend, A. R., Erisman, J. W., Bekunda, M., Cai, Z. C., Freney, J. R., Martinelli, L. A., Seitzinger, S. P., and Sutton, M. A.: Transformation of the nitrogen cycle: Recent trends, questions, and potential solutions, Science, 320, 889$892,2008$.

Goulding, K. W. T., Bailey, N. J., Bradbury, N. J., Hargreaves, P., Howe, M., Murphy, D. V., Poulton, P. R., and Willison, T. W.: Nitrogen deposition and its contribution to nitrogen cycling and associated soil processes, New Phytol., 139, 49-58, 1998.

Gong, X. Y, Chen, Q., Dittert, K., Taube, F., and Lin, S.: Nitrogen, phosphorus and potassium nutritional status of semiarid steppe grassland in Inner Mongolia, Plant Soil, 340, 265-278, 2011.

Grime, J. P.: Competitive exclusion in herbaceous vegetation, Nature, 242, 344-347, 1973.

Gross, K. L., Willig, M. R., Gough, L., Inouye, R., and Cox, S. B.: Patterns of species density and productivity at different spatial scales in herbaceous plant communities, Oikos, 89, 417-427, 2000.

Houlton, B. Z., Sigman, D. M., Schuur, E. A. G., and Hedin, L.O.: A climate-driven switch in plant nitrogen acquisition within tropical forest communities, P. Natl. Acad. Sci. USA, 104, 89028906, 2007.

Kahmen, A., Wanek, W., and Buchmann, N.: Foliar delta N-15 values characterize soil $\mathrm{N}$ cycling and reflect nitrate or ammonium preference of plants along a temperate grassland gradient, Oecologia, 156, 861-870, 2008.

Kang, L., Han, X. G., Zhang, Z. B., and Sun, O. J.: Grassland ecosystems in China: review of current knowledge and research advancement, Philos. T. R. Soc. B., 362, 997-1008, 2007. 
Koerselman, W. and Meuleman, A. F. M.: The vegetation N:P ratio: A new tool to detect the nature of nutrient limitation, J. Appl. Ecol., 33, 1441-1450, 1996.

Lauenroth, W. K., Dodd, J. L., and Sims, P. L.: The effect of water and nitrogen-induced stresses on plant community structure in a semiarid grassland, Oecologia, 36, 211-222, 1978.

Lauenroth, W. K., Milchunas, D. G., Sala, O. E., Burke, I. C., and Morgan, J. A.: Net primary production in the shortgrass steppe, in: Ecology of the Shortgrass Steppe: A long-term perspective, edited by: Lauenroth, W. K. and Burke, I. C., LTER Research Network Series, Oxford University Press, 270-305, 2008.

Liu, W. X., Zhang, Z., and Wan, S. Q: Predominant role of water in regulating soil and microbial respiration and their responses to climate change in a semiarid grassland, Global Change Biol., 15, 184-195, 2009.

Liu, X. J., Duan, L., Mo, J. M., Du, E. Z., Shen, J. L., Lu, X. K., Zhang, Y., Zhou, X. B., He, C. E., and Zhang, F. S.: Nitrogen deposition and its ecologyical impact in China: an overview, Environ. Pollut., doi:10.1016/j.envpol.2010.08.002, 2010.

Maskell, L. C., Smart, S. M., Bullock, J. M., Thompson, K., and Stevens, C. J.: Nitrogen deposition causes widespread loss of species richness in British habitats, Global Change Biol., 16, 671-679, 2010.

Mountford, J. O., Lakhani, K. H., and Kirkham, F. W.: Experimental assessment of the effects of nitrogen addition under haycutting and aftermath grazing on the vegetation of meadows on a Somerset peat moor, J. Appl. Ecol., 30, 321-332, 1993.

Pardo, L. H., Templer, P. H., Goodale, C. L., Duke, S., Groffman, P. M., Adams, M. B., Boeckx, P., Boggs, J., Campbell, J., Colman, B., Compton, J., Emmett, B., Gundersen, P., Kjonaas, J., Lovett, G., Mack, M., Magill, A., Mbila, M., Mitchell, M. J., McGee, G., McNulty, S., Nadelhoffer, K., Ollinger, S., Ross, D., Rueth, H., Rustad, L., Schaberg, P., Schiff, S., Schleppi, P., Spoelstra, J., and Wessel, W.: Regional assessment of N saturation using foliar and root delta N-15, Biogeochemistry, 80, 143-171, 2006.

Peppler-Lisbach, C. and Petersen, J.: Synopsis of the plant communities of Germany, Issue 8. Calluno-Ulicetea (G3), Part 1: Nardetalia strictae, Brush grasslands, Synopsis der Pflanzengesellschaften Deutschlands, 117 pp., 2001.

Phoenix, G. K., Hicks, W. K., Cinderby, S., Kuylenstierna, J. C. I., Stock, W. D., Dentener, F. J., Giller, K. E., Austin, A. T., Lefroy, R. D. B., Gimeno, B. S., Ashmore, M. R., and Ineson, P.: Atmospheric nitrogen deposition in world biodiversity hotspots: the need for a greater global perspective in assessing $\mathrm{N}$ deposition impacts, Global Change Biol., 12, 470-476, 2006.

Rao, L. E., Parker, D. R., Bytnerowicz, A., and Allen, E. B.: Nitrogen mineralization across an atmospheric nitrogen deposition gradient in Southern California deserts, J. Arid Enviro., 73, 920930, 2009.

Ren, H. Y., Xu, Z. W., Huang, J. H., Clark, C., Chen, S. P., and Han, X. G.: Nitrogen and water addition reduce leaf longevity of steppe species, Ann. Bot., 107, 145-155, 2011.

Roem, W. J. and Berendse, F.: Soil acidity and nutrient supply ratio as possible factors determining changes in plant species diversity in grassland and heathland communities, Biol. Conserv., 92, 151-161, 2000.
Sala, O. E., Chapin, F. S., Armesto, J. J., Berlow, E., Bloomfield, J., Dirzo, R., Huber-Sanwald, E., Huenneke, L. F., Jackson, R. B., Kinzig, A., Leemans, R., Lodge, D. M., Mooney, H. A., Oesterheld, M., Poff, N. L., Sykes, M. T., Walker, B. H., Walker, M., and Wall, D. H.: Biodiversity - Global biodiversity scenarios for the year 2100, Science, 287, 1770-1774, 2000.

SAS Institute: SAS User's Guide, SAS Institute, Cary, NC, 1996.

Song, L., Bao, X. M., Liu, X. J., and Zhang, F.S.: Impact of nitrogen deposition on plant community in a semi-arid temperate steppe in China, J. Arid Land, in review, 2011.

Stevens, C. J., Dise, N. B., Mountford, J. O., and Gowing, D. J.: Impact of nitrogen deposition on the species richness of grasslands, Science, 303, 1876-1879, 2004.

Stevens, C. J., Dise, N. B., Gowing, D. J. G., and Mountford, J. O.: Loss of forb diversity in relation to nitrogen deposition in the UK: regional trends and potential controls, Global Change Biol., 12, 1823-1833, 2006.

Storm, C. and Suss, K.: Are low-productive plant communities responsive to nutrient addition?, Evidence from sand pioneer grassland, J. Veg. Sci., 19, 343-354, 2008.

Suding, K. N., Collins, S. L., Gough, L., Clark, C., Cleland, E. E., Gross, K. L., Milchunas, D. G., and Pennings, S.: Functionaland abundance-based mechanisms explain diversity loss due to N fertilization, P. Natl. Acad. Sci. USA, 102, 4387-4392, 2005.

Sun, H. L.: Ecosystems of China, Science Press, Beijing, China, 2005.

Tilman, D., Reich, P. B., and Knops, J. M. H.: Biodiversity and ecosystem stability in a decade-long grassland experiment, Nature, 441, 629-632, 2006.

Tilsner, J., Wrage, N., Lauf, J., and Gebauer, G.: Emission of gaseous nitrogen oxides from an extensively managed grassland in NE Bavaria, Germany - I. Annual budgets of $\mathrm{N}_{2} \mathrm{O}$ and $\mathrm{NO}_{x}$ emissions, Biogeochemistry, 63, 229-247, 2003a.

Tilsner, J., Wrage, N., Lauf, J., and Gebauer, G.: Emission of gaseous nitrogen oxides from an extensively managed grassland in NE Bavaria, Germany - II. Stable isotope natural abundance of $\mathrm{N}_{2} \mathrm{O}$, Biogeochemistry, 63, 249-267, 2003b.

Vitousek, P. M., Aber, J. D., Howarth, R. W., Likens, G. E., Matson, P. A., Schindler, D. W., Schlesinger, W. H., and Tilman, G. D.: Human alteration of the global nitrogen cycle: Sources and consequences, Ecol. Appl., 7, 737-750, 1997.

Vitousek, P. M., Hattenschwiler, S., Olander, L., and Allison, S.: Nitrogen and nature, Ambio, 31, 97-101, 2002.

Wedin, D. A. and Tilman, D.: Influence of nitrogen loading and species composition on the carbon balance of grasslands, Science, 274, 1720-1723, 1996.

West, J. B., Hobbie, S. E., and Reich, P. B.: Effects of plant species diversity, atmospheric $\mathrm{CO}_{2}$, and $\mathrm{N}$ addition on gross rates of inorganic $\mathrm{N}$ release from soil organic matter, Global Change Biol., 12, 1400-1408, 2006.

Zhang, Y., Zheng, L. X., Liu, X. J., Jickells, T., Cape, J. N., Goulding, K. W. T., Fangmeier, A., and Zhang, F. S.: Evidence for organic $\mathrm{N}$ deposition and its anthropogenic sources in China, Atmos. Environ., 42, 1035-1041, 2008. 